\title{
Introduction to a New Open Access Journal by MDPI: Geographies
}

\author{
Luca Salvati \\ Department of Economics and Law, University of Macerata, Via Armaroli 43, I-62100 Macerata, Italy; \\ luca.salvati@unimc.it
}

Received: 17 November 2020; Accepted: 17 November 2020; Published: 24 November 2020

With big data and advanced tools becoming available to scientific communities, geographical research is constantly addressing new issues and questions [1], making use of both consolidated and original field techniques and quali-quantitative data analysis. The vast expertise in this scientific domain builds upon the legacy of centuries of practical experience; a well-grounded past is a pre-requisite to frame (and, sometimes, re-frame) the present research context and to creatively envision future scenarios [2]. International scientific journals are vital means of disseminating research findings.

Since evidence from the analysis of scientific databanks and repositories indicates how the geography discipline has a strong potential for growth and the dissemination of complex global problems, we established a new journal as an open access international outlet for research in a broad field of study. To this end, I do expect that Geographies MDPI will effectively contribute to challenging common assumptions and/or the research data in order to gain a clearer, more holistic understanding of the facts and findings in environmental and social sciences [3]. An effective support of science-policy and science-practice dialogues and interactions is expected from Geographies MDPI, stimulating the greater involvement of stakeholders and practitioners in the journal's life and consolidating open access and open data policies [4].

Our objective for the near future is to see Geographies MDPI included in the Scopus database, fostering open data policy within the community of complexity scientists, and gaining consideration within the broader international scientific community. However, while scientific articles are probably the most popular means of disseminating relevant findings in geography, citations do not say all about research quality. As a matter of fact, the number of articles published on high-impact peer-reviewed journals or the number of citations are not the only criteria to assess the quality and relevance of a scientific research. Moreover, a scientific journal is not just a 'static' collection of papers-its policy and practice can largely influence the progress of a given scientific community. Geographies MDPI will move exactly in these directions. This was the main reason why I have accepted the challenge of becoming the new Editor-in-chief of Geographies MDPI. My greatest hope is to contribute positively to the body of knowledge in the geography field, this being an appealing place for publication, open to scholars, professionals and practitioners worldwide, with no limit of age, nationality and background. My personal will is to do the best to support potential authors with suggestions, ideas and constructive criticism aimed at improving the quality of their own scientific product. I am convinced that the editorial process is just as satisfying as seeing one of my own papers published. Papers submitted to Geographies MDPI will be subject to a rigorous peer review procedure aimed at the rapid and wide dissemination of theoretical and practical studies.

Geographical thinking is applicable to different territorial contexts at dissimilar spatial scales, exploring local cultural, socioeconomic and physical backgrounds that can have a critical influence on regional contexts and planning practices [5]. With this perspective in mind, Geographies MDPI will develop and offer new strategies, visions and proposals on the role of sustainability and resilience related to urban and rural contexts [6], making essential a thorough reflection on how to manage 
large territories, studying their degree of resilience and future (sustainable) development [7]. New approaches and plans would also contribute to recovering high-quality natural areas, revitalizing the agricultural sector, which has experienced a strident decline in recent decades, and making the contexts in which people live more livable and resilient [8]. One example of the particularly intriguing themes in the contemporary debate is the nexus between territory and population [9]. The multifaceted nature of the mutual interactions between population and the environment has traditionally stimulated multiple perspectives of analysis, stemming from different theoretical grounds [10]. Geographical notions constitute the indispensable ground for the verification of apparent and more latent mechanisms of growth and change with data-driven or model-driven operational approaches [11], making use of multidimensional indicators [12,13]. Considering these and many other issues, Geographies MDPI offers a multidisciplinary arena to discuss the deserving issues pertinent (but not exclusive) to the Geographical disciplines, stimulating literature reviews, position papers, commentaries, new theoretical frameworks and empirical approaches, comparative works, and case studies. In this way, Geographies MDPI will be committed to help policy-makers to manage the new chances set up by a particularly complex and dynamic socioeconomic scenario worldwide.

Conflicts of Interest: The author declares no conflict of interest.

\section{References}

1. Brenner, N.; Peck, J.; Theodore, N. Variegated neoliberalization: Geographies, modalities, pathways. Global Netw. 2020, 10, 182-222. [CrossRef]

2. Miller, H.J.; Goodchild, M.F. Data-driven geography. GeoJournal 2015, 80, 449-461. [CrossRef]

3. Riley, M.; Harvey, D. Talking geography: On oral history and the practice of geography. Soc. Cult. Geogr. 2007, 8, 345-351. [CrossRef]

4. Harvey, D. The geographies of critical geography. Trans. Inst. Br. Geogr. 2006, 31, 409-412. [CrossRef]

5. Claval, P.; Thompson, I.B. An Introduction to Regional Geography; Wiley Blackwell: Hoboken, NJ, USA, 1998; pp. 282-283.

6. Pumain, D. Une approche de la complexité en géographie. Géocarrefour 2003, 78, 25-31. [CrossRef]

7. Prezioso, M. Geographical and territorial vision facing the crisis. J. Glob. Policy Gov. 2013, 2, 27-44. [CrossRef]

8. Linke, A.M.; O'Loughlin, J. Spatial analysis. In A Companion to Political Geography, 2nd ed.; Wiley Blackwell: Hoboken, NJ, USA, 2015; p. 189.

9. Maloutas, T. Contextual diversity in gentrification research. Crit. Sociol. 2012, 38, 33-48. [CrossRef]

10. Vidal, M.; Domene, E.; Sauri, D. Changing geographies of water-related consumption: Residential swimming pools in suburban Barcelona. Area 2011, 43, 67-75. [CrossRef]

11. Imeson, A. Desertification, Land Degradation and Sustainability; John Wiley \& Sons: Hoboken, NJ, USA, 2012.

12. Juntti, M.; Wilson, G.A. Conceptualizing desertification in Southern Europe: Stakeholder interpretations and multiple policy agendas. Eur. Environ. 2005, 15, 228-249. [CrossRef]

13. Wyly, E.K. Continuity and change in the restless urban landscape. Econ. Geogr. 1999, 75, 309-338. [CrossRef]

Publisher's Note: MDPI stays neutral with regard to jurisdictional claims in published maps and institutional affiliations.

(C) 2020 by the author. Licensee MDPI, Basel, Switzerland. This article is an open access article distributed under the terms and conditions of the Creative Commons Attribution (CC BY) license (http://creativecommons.org/licenses/by/4.0/). 